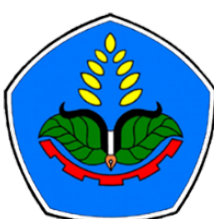

AGROPROSS

National Conference

Proceedings of Agriculture
Proceedings:

PeningkatanProduktivitasPertanian Era Society 5.0 PascaPandemi

Tempat : Politeknik Negeri Jember

Tanggal : 22 Juli 2021

Publisher :

Agropross, National Conference Proceedings of Agriculture

ISBN : 978-623-94036-6-9

DOI : 10.25047 /agropross.2021.222

\title{
Analisis Tingkat Kesukaan Konsumen Pada Produk Sirup Kopi dengan Penambahan Susu Full Cream
}

\author{
Author(s): Usken Fisdiana ${ }^{(1)^{*}}$, Rima Ajeng Anggriani ${ }^{(1)}$, Budi Hariyanto ${ }^{(1)}$, \\ Faridatul Hasanah $^{(1)}$ \\ (1) Jurusan Produksi Pertanian Politeknik Negeri Jember \\ * Corresponding author: usken_fisdiana@polije.ac.id
}

\begin{abstract}
Coffee syrup is one of the processed coffee bean products based on contemporary drinks with a more practical presentation. The addition of milk is an effort to attract consumers' interest as well as develop a variety of flavors and increase the selling value. Therefore, the purpose of this study was to analyze the level of consumer preference for Robusta coffee syrup with the addition of full cream milk through organoleptic tests. The research was carried out at the Agricultural Product Processing Laboratory of Politeknik Negeri Jember in June-August 2020 using the single factor Randomized Block Design (RAK) method and a 5\% BNT follow-up test. The treatment was in the form of a comparison between full cream milk powder and coffee powder which had a ratio of 1/7; 1.5/7 and 2/7. The level of preference testing was carried out on 75 male and female panelists aged 18-25 years. The results showed that 1) The level of consumer preference for coffee syrup drinks with the addition of full cream milk was different in viscosity which had the highest average hedonic value of 8.40 in a mixture of adding full cream milk as much as 1.5/7 parts of coffee powder with a thicker texture. and creamy, 2) The level of consumer preference for coffee syrup drinks with the addition of full cream milk does not differ in aroma, taste, color, sediment and aftertaste with an average hedonic value ranging from 7.64 to 8.96 which indicates a moderate to liking level.
\end{abstract}

Keywords:

hedonic,

coffee,

syrup,

full cream milk

\section{Kata Kunci: ABSTRAK}

hedonik,

Sirup kopi merupakan salah satu produk olahan biji kopi berbasis minuman kekinian dengan penyajian yang lebih praktis. Penambahan susu merupakan upaya untuk menarik minat

kopi, konsumen sekaligus mengembangkan variasi rasa dan meningkatkan nilai jual. Oleh karena itu tujuan penelitian ini adalah menganalisis tingkat kesukaan konsumen pada produk sirup kopi sirup, dengan penambahan susu full cream melalui uji organoleptik. Penelitian dilaksanakan di laboratorium Pengolahan Hasil Pertanian Politeknik Negeri Jember pada bulan Juni-Agsutus 2020 dengan menggunakan metode Rancangan Acak Kelompok (RAK) faktor tunggal dan uji susu full cream lanjut BNT 5\%. Perlakuan berupa perbandingan antara susu bubuk full cream dengan bubuk kopi yang mempunyai komposisi perbandingan $1 / 7 ; 1,5 / 7$ dan $2 / 7$. Pengujian tingkat kesukaan dilakukan kepada 75 panelis laki-laki dan perempuan berumur 18-25 tahun. Hasil penelitian menunjukkan bahwa 1) Tingkat kesukaan konsumen terhadap minuman sirup kopi dengan penambahan susu full cream berbeda pada kekentalan yang mempunyai rerata nilai hedonik tertinggi 8,40 pada campuran penambahan susu full cream sebanyak 1,5/7 bagian dari bubuk kopi dengan tekstur lebih kental dan creamy, 2) Tingkat kesukaan konsumen terhadap minuman sirup kopi dengan penambahan susu full cream tidak berbeda pada aroma, rasa, warna, endapan dan aftertaste dengan rerata nilai hedonik berkisar antara 7,64 - 8,96 yang menandakan tingkat kesukaan moderat sampai suka. 


\section{PENDAHULUAN}

Dewasa ini pergeseran budaya akibat globalisasi semakin terasa. Salah satunya adalah budaya meminum kopi. Apabila di masa sebelumnya budaya minum kopi lebih banyak dilakukan oleh kalangan tertentu saja yang didasarkan pada selera tiap orang, di masa sekarang minum kopi telah bergeser menjadi bagian dari gaya hidup masyarakat utamanya masyarakat perkotaan. Persepsi akan kebutuhan dan pola konsumsi dalam minum kopi meningkat seirama dengan modernisasi perkembangann zaman (Solikatun, Kartono, dan Demartoto, 2015).

Pergeseran budaya minum kopi tersebut ditunjukkan dengan adanya peningkatan konsumsi kopi di dalam negeri. Menurut Komisi Pengawas Persaingan Usaha (2020) tingkat konsumsi kopi dalam negeri selama periode tahun 2010 s/d 2014 ada kecenderungan meningkat meski terlihat stagnan. Pada tahun 2010 tercatat sebesar 0,80 $\mathrm{Kg} / \mathrm{kapita} /$ tahun dan pada tahun 2019 konsumsi kopi domestik meningkat menjadi $1,13 \mathrm{Kg} / \mathrm{kapita} /$ tahun.

Konsumsi kopi dalam beberapa tahun belakangan ini tidak hanya berbentuk kopi bubuk (roast and ground) tetapi sudah terdapat diversifikasi produk olahan kopi yang beredar di pasaran antara lain kopi instan, kopi siap minuman dengan berbagai rasa seperti vanilla, cocoa dan lainnya, serta kopi mix antara lain herbal coffe, Latte , Cappucinno, Mochaccino, Americano dan lain lain. Produk produk olahan kopi tersebut dapat diproses melalui industri kopi olahan skala besar, skala menengah dan skala kecil (Home Industry). Selain ketiga jenis industri tersebut, beberapa tahun terakhir bermunculan café atau coffe shop yang menyajikan minuman kopi jenis expresso atau minuman kopi susu kekinian sehingga secara signifikan juga menyumbang kenaikan konsumsi kopi dalam negeri.
Stokes et al. (2017) juga melaporkan bahwa pola konsumsi kopi konsumen telah berevolusi serta digolongkan sesuai kategori, yaitu kopi organik dan kopi specialty yang populer di pasar saat ini. Terdapat pula banyak jenis dan gaya kopi yang tersedia untuk konsumen dengan pilihan kopi berdasarkan banyak kombinasi asal, jenis, metode penggilingan, metode pembuatan, pengemasan dan variasi rasa.

Pekebun atau petani kopi yang juga merupakan pelaku usaha dibidang industri olahan kopi biasanya berada pada tingkatan home industry. Produk olahan yang biasa dihasilkan adalah kopi bubuk (roast and ground) karena proses pengolahannya mudah, dapat dilakukan dengan alat yang sederhana serta tidak membutuhkan biaya tinggi. Alternatif yang bisa ditawarkan untuk menambah varian produk olahan kopi bagi petani atau pelaku industri pada tingkat home industry adalah jenis produk yang bisa diproses secara mudah dan sederhana yaitu sirup kopi.

Berdasarkan Standar Nasional (2013), sirup adalah produk minuman yang dibuat dari campuran air dan gula dengan kadar larutan gula minimal $65 \%$ dengan atau tanpa bahan pangan lain dan atau bahan tambahan pangan yang diijinkan sesuai ketentuan yang berlaku. Sirup kopi merupakan salah satu produk pengembangan olahan biji kopi berbasis minuman yang dengan keberadaanya menjadikan produk kopi lebih bervariasi.. Apabila pada dasarnya minuman kopi lebih banyak disukai oleh kaum laki-laki pada jenjang umur tertentu, tetapi produk sirup kopi ini dapat menjangkau kaum perempuan bahkan anak-anak dengan penyajian yang disukai seperti penambahan es batu, penyajian dingin, ataupun hangat. Selain dapat disajikan sesuai selera, rasa sirup kopi tidak jauh berbeda dari minuman kopi pada dasarnya dan juga bisa dikatakan relatif praktis dalam penyajiannya. 
Produk sirup kopi sudah ada dipasaran dengan bermacam rasa, baik yang diproduksi oleh industri besar maupun industri kecil. Di kalangan menengah ke atas produk ini sudah familier tetapi di kalangan bawah belum banyak yang mengenal, karena selama ini.yang mereka konsumsi kebanyakan minuman kopi hasil penyeduhan dari bubuk kopi atau mungkin ada tambahan bahan lain untuk menambah citarasa seduhannya. saat ini masyarakat terutama generasi milenial baik di perkotaan maupun di pedesaan lebih menyukai minuman kopi dengan tambahan susu, coklat, dan lain- lain. Oleh sebab itu untuk menambah varian produk sirup kopi yang diminati masyarakat terutama kaum milenial adalah dengan membuat olahan minuman kopi ini dengan tambahan produk susu yaitu susu full cream.

Susu merupakan suatu emulsi lemak dalam air yang berasal dari sekresi ambing hewan. Kadar air susunya memiliki ratarata $87,5 \%$ yang mengandung zat gizi penting, seperti protein, lemak, gula, vitamin, dan mineral. Kadar protein dalam susu memiliki mutu yang sangat tinggi, dengan kadarnya dalam susu segar sebesar $3,5 \%$, dan mengandung lemak yang diperkirakan sama dengan protein. Kandungan gula dalam susu berupa laktosa yang memiliki daya kemanisan sangat rendah. Mineral yang ada dalam susu seperti kalsium, fosfor, klorida, magnesium, dan natrium yang terlarut dalam air. Sedangkan vitamin dalam susu berupa niasin dan riboflavin (Wardana, 2012).

Berdasarkan kadar lemak dalam susu, produk susu dibedakan menjadi dua yaitu, susu full cream dan susu skim. Susu skim memiliki kandungan lemak yang lebih sedikit, sedangkan susu full cream memiliki kandungan lemak lebih banyak yaitu sekitar 3,25\%. Apabila ditinjau dari segi rasa susu full cream terasa lebih gurih sedangkan susu skim terasa manis yang juga menandakan memiliki kandungan gula yang lebih tinggi (Kompasiana, 2018).

Berdasar uraian di atas maka penelitian tentang analisa tingkat kesukaan konsumen terhadap produk sirup kopi dengan penambahan susu bubuk full cream dilakukan dengan tujuan untuk mengetahui tingkat kesukaan konsumen terhadap produk sirup kopi dengan penambahan susu full cream melalui uji organoleptik. Tingkat kesukaan konsumen sebagai fungsi dari intensitas yang dirasakan akan memberikan interpretasi data konsumen yang lebih variatif dan berguna untuk dikaji lebih lanjut (Li et al., 2014).

\section{BAHAN DAN METODE}

Penelitian ini dilaksanakan

di Laboratorium Pengolahan Hasil Pertanian Politeknik Negeri Jember pada bulan Juli hingga Agustus 2020. Metode penelitian yang digunakan adalah Rancangan Acak Kelompok faktor tunggal. Adapun perlakuan penambahan susu full cream pada sirup kopi terdiri dari

$\mathrm{P} 1=1.0$ susu bubuk full cream $: 7$ bubuk kopi

$\mathrm{P} 2=1,5$ susu bubuk full cream $: 7$ bubuk kopi

P3 $=2.0$ susu bubuk full cream : 7 bubuk kopi

Jika dari analisa sidik ragam (ANOVA) menunjukkan beda nyata maka akan dilakukan uji BNT dengan taraf 5\%. Data diambil berdasarkan uji organoleptik (uji hedonik), sedangkan parameter yang diamati meliputi warna, aroma, rasa, kekentalan dan aftertaste.

Alat dan bahan yang digunakan dalam penelitian adalah timbangan digital, mesin ayak biji kopi, mesin sangrai biji kopi, mesin penghalus biji kopi, kulkas, sendok, panci, gelas ukur, kompor, pengaduk, saringan, mangkuk, pisau/gunting, botol kaca \& tutup, corong, kulkas, oven, sealer , plastik, biji kopi 
robusta, gula, susu full cream, air, CMC, Natrium benzoat, dan Asam sitrat.

Pelaksanaan penelitian terdiri atas :

1. Pembuatan bubuk kopi : biji kopi robusta disortir kemudian disangrai dengan alat sangria sampai biji berwarna medium ke dark. Setelah disimpan selama 24 jam, biji kopi sangrai dihaluskan menggunakan grinder menjadi bubuk kopi

2. Pembuatan ekstrak kopi: merebus air sebanyak 2 liter, setelah mendidih bubuk kopi seberat 600 gram dimasukkan dan dilakukan pengadukan sampai larutan homogen dan beberapa saat kemudian kompor dimatikan. Setelah larutan dingin dilakukan penyaringan menggunakan kain saring dan disimpan di lemari pendingin selama 24 jam.

3. Pembuatan sirup : memasakan ekstrak kopi dan gula dengan perbandingan 1:1. Serta susu full crem sesuai dengan perlakuan. Setelah gula melarut ditambahkan CMC 1 gram untuk setiap 1 liter ekstrak kopi, yang sebelumnya dilarutkan dengan air. Setelah larutan mendidih beberapa saat dimasukkan Natrium benzoat 1 gram dan Asam sitrat 0,5 gram untuk setiap1 liter ekstrak kopi, kemudian ditunggu sekitar 3 menit lalu kompor dimatikan dan sirup didinginkan. Penyaringn dilakukan setelah sirup menjadi dingin .

4. Pengemasan sirup kopi: menyiapkan botol kaca yang sudah disterilkan dalam oven selama 3 jam dengan suhu $130^{\circ} \mathrm{C}$, kemudian sirup yang sudah dingin dimasukkan ke dalam botol kemasan dan ditutup serta diberikan label/tanda sesuai dengan perlakuan.

Pengujian organoleptik merupkan ilmu yang mempelajari cara-cara pengujian terhadap sifat karkteristik bahan mnggunakan indera manusia termasuk indera penglihatan, pembau, perasa peraba dan pendengar. Uji organoleptik banyak digunakan untuk menilai suatu komoditi makanan, khususnya produk-produk kenikmatan. Pengujian ini banyak disenangi karena langsung menilai kesukaan manusia sebagai konsumen (Sumartono dkk, 2005).

Pengujian organoleptik pada penelitian ini menggunakan uji hedonic atau uji kesukaan dengan panelis konsumen berjumlah 75 0rang. Kriteria panelis adalah berumur antara $18-25$ tahun, berjenis kelamin laki-laki dan perempuan. Berikut adalah tahapan proses uji organoleptik :

1. Panelis mengisi data pendukung pada kuisioner sebagai panelis uji organoleptik

2. Panelis melakukan pengujian terhadap 3 sampel yang disajikan dan memberikan penilaian terhadap setiap parameter yang telah dicantumkan pada kuisioner

3. Panelis mengisi penilaian pengujian organoleptik pada lembar kuisioner dengan mengisi/menandai diagram garis sepanjang $14 \mathrm{~cm}$ sebagai skala pengukurannya.

4. Melakukan tabulasi data terhadap penilaian yang telah dilakukan panelis pada lembar kuisioner terhadap parameter warna, aroma, rasa, kekentalan dan aftertaste

5. Nilai skala hedonik yang digunakan adalah sebagai berikut :

Nilai $0,0-2,0=$ sangat tidak suka sekali

Nilai $2,1-4,0=$ sangat tidak suka

Nilai $4,1-6,0=$ kurang suka

Nilai $6,1-8,0=$ moderat

Nilai $8,1-10,0=$ suka

Nilai $10,1-12,0=$ sangat suka

Nilai $12,1-14,0=$ sangat suka sekali

\section{HASIL DAN PEMBAHASAN}

Hasil analisa sidik ragam pada semua parameter pengamatan berdasarkan tingkat kesukaan konsumen pada produk 
sirup kopi dengan penambahan susu full cream disajikan pada Tabel 1.

Tabel 1. Rangkuman Analisa Sidik Ragam Tingkat Kesukaan Konsumen Pada Produk Sirup Kopi Dengan Penambahan Susu Full Cream

\begin{tabular}{|c|c|c|c|c|c|c|c|c|c|}
\hline \multirow{2}{*}{$\begin{array}{l}\text { Sidik } \\
\text { Ragam }\end{array}$} & \multirow{2}{*}{$\mathrm{Db}$} & \multicolumn{6}{|c|}{ F. Hitung } & \multicolumn{2}{|c|}{ F. Tabel } \\
\hline & & Aroma & Rasa & Warna & Kekentalan & Endapan & Aftertaste & $5 \%$ & $1 \%$ \\
\hline Perlakuan & 2 & $0,28 \mathrm{~ns}$ & $0,61 \mathrm{~ns}$ & $1,21 \mathrm{~ns}$ & $3,64 *$ & $0,67 \mathrm{~ns}$ & $1,74 \mathrm{~ns}$ & 3,05 & 4,75 \\
\hline Ulangan & 74 & $2,33 * *$ & $1,55^{* *}$ & $1,83 * *$ & $2,76 * *$ & $2,08 * *$ & $1,22 \mathrm{~ns}$ & 1,38 & 1,57 \\
\hline Galat & 148 & & & & & & & & \\
\hline Total & 224 & & & & & & & & \\
\hline Keterangan & 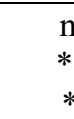 & & $\begin{array}{l}\text { signifil } \\
\text { da nya } \\
\text { da san }\end{array}$ & perbed & & & & & \\
\hline
\end{tabular}

Berdasarkan hasil analisa sidik ragam yang terlihat pada Tabel 1 menunjukkan bahwa hanya parameter kekentalan yang berbeda nyata, sedangkan parameter warna, aroma, rasa dan aftertaste tidak berpengaruh nyata atau berbeda tidak nyata terhadap tingkat kesukaan konsumen pada produk sirup kopi dengan penambahan susu full cream. Parameter yang menunjukkan hasil berbeda nyata akan dilakukan uji lanjut menggunakan uji BNT $5 \%$ untuk mengetahui nilai beda nyata terkecil dari rerata semua perlakuan.

Selanjutnya hasil penilian hedonik dari panelis terhadap parameter aroma, rasa, warna, endapan dan aftertaste tersaji pada Gambar 1.

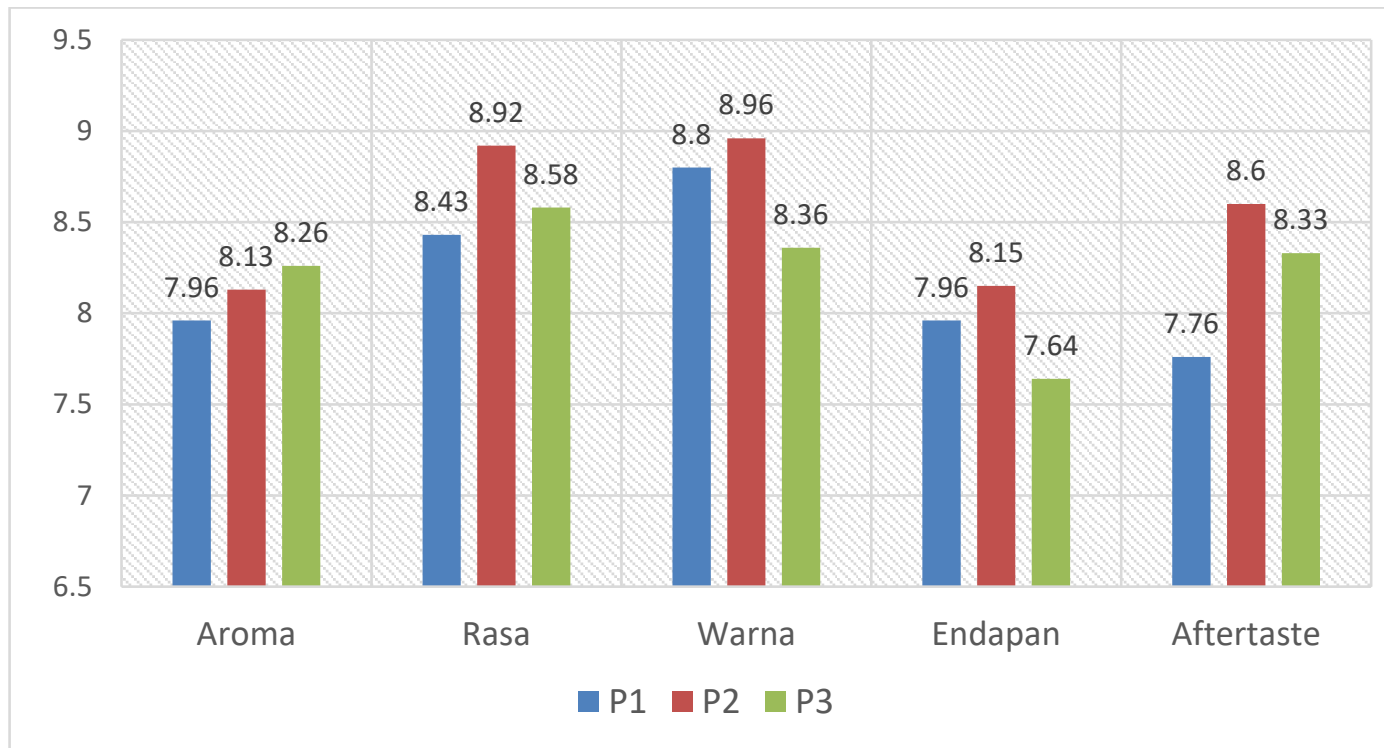

Gambar 1. Rangkuman Rerata Nilai Hedonik Aroma. Rsa, Warna, Endapan dan Aftertaste Tingkat Kesukaan Konsumen Pada Sirup Kopi Dengan Penambahan Susu Full Cream

\section{Aroma}

Hasil analisa sidik ragam parameter aroma pada Tabel 1 terlihat bahwa secara statistik menunjukkan pengaruh yang berbeda tidak nyata. Berdasarkan Gambar 1 diketahui bahwa penilaian hedonik terhadap aroma, nilai rerata dari $\mathrm{P} 1$ memperlihatkan pada tingkatan moderat dengan nilai rerata 7,96 , sedangkan perlakuan P2 dan P3 berada pada tingkatan suka dengan nilai rerata 8,13 dan 8,26 untuk perlakuan $\mathrm{P} 3$ 
Penilaian hedonik terhadap aroma produk sirup kopi yang dihasilkan dengan penambahan susu full cream cenderung sama, hal tersebut disebabkan karena aroma dari susu full cream yang ditambahkan tidak begitu kuat dibandingkan dengan aroma kopi. Menurut Soeparno (1992) menyatakan bahwa susu biasanya memiliki aroma yang tidak menonjol. Sehingga apabila dicampur dengan kopi aroma yang dominan muncul adalah aroma kopi.

Dominansi aroma kopi diperkuat oleh pemakaian jenis kopi robusta pada produk sirup kopi yang dihasilkan. Menurut Widyotomo (2017), kelompok penting komponen volatil pada biji kopi adalah senyawa belerang, pirazin, piridin, pirol, oksazol, furan, senyawa karbonil dan fenol. Kandungan senyawa belerang pada biji kopi sangat sedikit, tetapi sangat penting pada aroma kopi dan senyawa Dimetilsulfida mempunyai peran sangat penting pada intensitas aroma. Selanjutnya Misnawi dkk (2017) menyatakan dengan teknik kromatografi gas dapat diketahui perbedaan kandungan zat volatile dari kopi robusta dan arabika. Kandungan fenol, maltol, alkipirol dan senyawa sulfur relatif lebih tinggi pada kopi robusta, sedangkan kandungan cycloten hidroksi maltol dan furfuriol relative lebih tinggi pada kopi arabika.

\section{Rasa}

Parameter rasa secara statistik menunjukkan pengaruh berbeda tidak nyata. Berdasarkan penilaian hedonik pada Gambar 1 dapat diketahui bahwa nilai rerata ketiga perlakuan menunjukkan pada tingkat suka dengan nilai rerata dari P1 adalah 8,43, P2 sebesar 8,92 dan P 3 dengan nilai 8,58 . Asumsi rasa terkadang bisa juga tidak valid karena perbedaan kesukaan. Tindakan menambahkan lebih banyak ekstrak kopi ke dalam minuman rasa kopi dapat meningkatkan rasa kopi, yang dianggap sebagai faktor positif bagi penerimaan konsumen, tetapi juga dapat meningkatkan kepahitan yang dapat merugikan selera konsumen ( $\mathrm{Li}$ et al., 2014).

Salah satu tujuan dari penambahan susu full cream pada penelitian ini adalah membuat rasa produk sirup kopi menjadi lebih creamy. Susu biasanya memiliki rasa khas seperti creamy, dan jenis susu full cream memiliki rasa yang lebih gurih dibandingkan dengan susu jenis lain karena memiliki kandungan lemak yang lebih banyak (Domina, 2018). Menurut SNI (2015), kandungan lemak pada susu bubuk full cream minimal $26 \%$ dan kurang dari $42 \%$, sedangkan kandungan lemak dari susu bubuk skim maksimal 1,5\%. Penilaian hedonik terhadap rasa sirup kopi pada ketiga perlakuan yang tidak berbeda jauh menunjukkan bahwa dengan penambahan susu full cream mulai dengan perbandingan antara susu full cream dan bubuk kopi $1: 7,1,5: 7$ dan 2:7 sudah cukup membuat konsumen menyukainya.

\section{Warna}

Hasil analisa sidik ragam parameter warna pada Tabel 1 terlihat bahwa secara statistik menunjukkan pengaruh yang berbeda tidak nyata. Berdasarkan penilaian hedonic pada Gambar1 terlihat bahwa nilai rerata ketiga perlakuan menunjukkan pada tingkatan suka. Nilai rerata pada perlakuan P1 sebesar 8,88 , untuk P2 dengan nilai 8,96 dan P3 pada nilai 8,36.

Warna sirup kopi dari ketiga perlakuan tidak berbeda jauh dan didominasi oleh warna gelap kehitaman yang berasal dari warna biji kopi. Biji kopi akan mengalami perubahan warna dari hijau kecoklatan menjadi coklat kehitaman dan hitam akibat proses penyangraian. Menurut Mulato, dkk. (2010) selama proses penyangraian, ada tiga tahapan reaksi fisik dan kimiawi yang berjalan 
secara berurutan, yaitu penguapan air, penguapan senyawa volatil dan pirolisis. Pirolisis pada dasarnya merupakan reaksi dekomposisi senyawa hidrokarbon antara lain karbohidrat, hemiselulosa dan selulosa yang ada di dalam biji kopi sebagai akibat dari pemanasan. Reaksi ini umumnya terjadi setelah suhu sangrai di atas $180^{\circ} \mathrm{C}$. Secara kimiawi proses ini ditandai dengan evolusi gas $\mathrm{CO}_{2}$ dalam jumlah banyak dari ruang sangrai. Sedang secara fisik, pirolisis ditandai dengan perubahan warna biji kopi yang semula kehijauan menjadi coklat muda lalu menjadi coklat kayu manis hitam dengan permukaan berminyak.

Penambahan susu full cream yang lebih banyak pada sirup kopi sedikit memberikan warna putih, sehingga produk sirup kopi dengan kandungan susu full cream yang lebih banyak memiliki warna hitam yang agak kecoklatan dan agak pucat. Susu memiliki warna putih kebiruan-biruan sampai dengan kecoklatan. Warna putih susu adalah hasil penyebaran butiran-butiran lemak, kalsium kaseinat, dan kalsium fosfat pada susu. Warna kuning pada susu merupakan larutnya vitamin A, kolesterol, dan pigmen karoten dalam globula lemak (Winarno, 2007).

\section{Kekentalan}

Hasil analisa sidik ragam pada Tabel 1 terlihat bahwa secara statistik menunjukkan pengaruh yang berbeda nyata sehingga diuji lanjut menggunakan BNT (Beda Nyata Terkecil) pada taraf 5\% yang disajikan pada Tabel 2 .

Tabel 2. Rerata Nilai Hedonik Kekentalan Tingkat Kesukaan Konsumen Pada Sirup Kopi Dengan Penambahan Susu Full Cream

\begin{tabular}{cccc}
\hline & Perlakuan & Rerata & Notasi \\
\hline & P1 & 7,65 & $\mathrm{a}$ \\
& P2 & 8,40 & $\mathrm{~b}$ \\
$\mathrm{P} 3$ & 7,56 & $\mathrm{a}$ \\
\hline Keterangan & : angka-angka yang diikuti dengan huruf kecil yang sama menunjukkan berbeda tidak nyata \\
& (non signifikan) pada uji BNT 5\%.
\end{tabular}

Kekentalan merupakan unsur sifat organoleptik yang dinilai orang pada suatu bahan melalui beberapa cara yaitu diraba oleh jari, diamati oleh mata, dan dirasakan oleh lidah dalam rongga mulut. Interaksi persepsi dapat terjadi, ketika individu merasakan intensitas yang sama dari konsentrasi fisik yang berbeda, atau ketika bahan tunggal dapat berkontribusi lebih dari satu atribut sensorik (Li et al., 2014).

Sunarharum dkk (2019), menyatakan bahwa penambahan susu pada kopi memberikan body yang lebih baik. Teksturnya lebih kental dan creamy karena adanya emulsi susu yang bercampur dengan ekstrak kopi. Sistem emulsi minyak dalam air pada susu, droplet/globula minyak atau droplet emulsi berinteraksi dengan saliva dalam mulut sehingga memenuhi dan melapisi rongga mulut, memberikan kesan tekstur kental/tebal, lembut (smooth) dan dipersepsikan sebagai creamy.

Berdasarkan uji lanjut BNT 5\% pada Tabel 2 menunjukkan bahwa perlakuan P1 tidak berbeda nyata dengan perlakuan P3, tetapi berbeda nyata dengan perlakuan $\mathrm{P} 2$, dan perlakuan $\mathrm{P} 2$ berbeda nyata dengan perlakuan P3. Perlakuan P2 dengan penambahan susu full cream sebanyak 1,5/7 bagian dari bubuk kopi menunjukkan nilai rerata yang lebih tinggi dari perlakuan lain yaitu sebesar 8,40. Semakin banyak penambahan susu full cream akan 
meningkatkan kesukaan konsumen terhadap parameter kekentalan tetapi penambahan susu full cream yang lebih banyak menurunkan tingkat kesukaan konsumen. Hal tersebut disebabkan karena penambahan susu full cream sebanyak 2/7 bagian bubuk kopi akan menyebabkan kekentalan pada sirup kopi menjadi lebih tinggi karena kandungan lemaknya lebih banyak.

\section{Endapan}

Hasil analisa sidik ragam parameter endapan pada Tabel 1 terlihat bahwa secara statistik menunjukkan pengaruh yang berbeda tidak nyata. Berdasar gambar 1 pada penilaian hedonik terlihat bahwa perlakuan P2 yang disukai konsumen dengan 8,15. Sedangkan perlakuan P1 dan P2 pada tingkat moderat dengan nilai rerata 7,96 dan 7,64. Persepsi setiap orang terhadap adanya endapan atau ampas pada minuman khususnya minuman berbasis kopi berbeda-beda. Endapan merupakan zat yang tidak larut dalam suatu larutan. Penyajian dari sirup kopi susu ini memiliki endapan yang berasal dari ampas ekstrak kopi dan juga bubuk susu full cream yang tidak terlarut. Menurut Wardana (2012), ketidaklarutan susu pada larutan merupakan tanda kerusakan susu akibat denaturasi protein yang terjadi karena pemanasan diatas suhu $60^{\circ} \mathrm{C}$. Ukuran lubang saringan pada waktu ekstraksi yang diduga kurang kecil sehingga menyebabkan partikel bubuk kopi dan gumpalan susu yang halus masih terikut.

\section{Aftertaste}

Hasil analisa sidik ragam parameter aftertaste pada Tabel 1 terlihat bahwa secara statistik menunjukkan pengaruh yang berbeda tidak nyata. Berdasarkan penilaian hedonik (Gambar 1) nilai rerata perlakuan P2 dan P3 berada pada tingkat suka dengan nilai rerata 8,6 dan 8,33 , sedangkan pada $\mathrm{P} 1$ pada tingkat moderat dengan nilai rerata 7,76
Aftertaste merupakan lamanya rasa dan aroma (flavor positif) yang tertinggal setelah cairan ditelan atau dibuang. Persepsi enak atau tidak aftertaste dari suatu minuman biasanya didasarkan pada penilaian subjektif yang artinya berbedabeda setiap orang. Dari Gambar 4.1 penambahan susu full cream menunjukkan kecenderungan bahwa semakin banyak pemberian susu full cream akan meningkatkan tingkat kesukaaan konsumen terhadap parameter aftertaste dari moderat menjadi suka. Menurut Sunarharum dkk (2019), penambahan susu dapat menurunkan secara signifikan intensitas aroma kopi karena adanya penurunan pelepasan aroma 2-furfuritiol yang merupakan senyawa aroma utama kopi seduh. Selain terjadi penurunan intensitas aroma kopi, susu memiliki kandungan laktosa yang tinggi yang mana memiliki hubungan yang erat dengan bau atau aroma yang disenangi (Maitimu, Legowo, dan Al-Baari, 2012).

\section{KESIMPULAN}

Berdasalkan hasil uji organoleptik maka dapat diambil kesimpulan sebagai berikut :

1. Tingkat kesukaan konsumen terhadap minuman sirup kopi dengan penambahan susu full cream berbeda pada kekentalan yang mempunyai rerata nilai hedonik tertinggi 8,40 pada campuran penambahan susu full cream sebanyak 1,5/7 bagian dari bubuk kopi dengan tekstur lebih kental dan creamy.

2. Tingkat kesukaan konsumen terhadap minuman sirup kopi dengan penambahan susu full cream tidak berbeda pada aroma, rasa, warna, endapan dan aftertaste dengan rerata nilai hedonik berkisar antara 7,64 8,96 yang menandakan tingkat kesukaan moderat sampai suka. 


\section{DAFTAR PUSTAKA}

Badan Standarisasi Nasional. 2013. "Standar Nasional Indonesia: Sirup". Edisi Online.

https://kupdf.net/download/snisirup_58ec4250dc0d608178da9810_ pdf. [22 April 2020].

Badan Standardisasi Nasional, 2015. "Standar Nasional Indonesia: Susu Bubuk" Edisi Online. https://kupdf.net/download/31995271 9-16614-sni-2970-2015-susu-bubukpdf_58ca032adc0d60ba5b339028_pd f. [10 Juli 2021]

Domina, W. 2018. "Perbedaan Susu Skim dengan Susu Full cream, Manakah yang Cocok untuk Diet ?". Dalam Kompasiana. Edisi 19 Desember 2018.

https://www.kompasiana.com/leoric/5 c19ed3e43322f59a157c414/perbedaa n-susu-.skim-dengan-susu-full-creammanakah-yang-cocok-untuk-diet\#. [19 Juni 2020]

Komisi Pengawasan Persaingan Usaha,2020. Penelitian Pelaku Usaha dan Struktur Pasar Pada Komoditi Kopi. https://kppu.go.id/wpcontent/uploads/2021/01/Kopi-

Ringkasan-Eksekutif.pdf. $\quad[10 \quad$ Juli 2021]

Li B, JE Hayes and GR Ziegler. 2014. Interpreting consumer preferences: physicohedonic and psychohedonic models yield different information in a coffee flavored dairy beverage. Food Qual Prefer. (36): 27-32. doi:10.1016/j.foodqual.2014.03.001

Mulato, S., Widyotomo, S., \& Suharyanto, E. 2010. Teknologi Proses dan Pengolahan Produk Primer dan Sekunder Kopi. Pusat Penelitian Kopi Dan Kakao, Jember

Maitimu, C.V., A. M. Legowo., dan A. N. Al-Baarri. 2012. "Parameter Keasaman Susu Pasteurisasi dengan Penambahan Ekstrak Daun Aileru (Wrightia caligria)". J. Aplikasi
Teknologi Pangan”. Vol. 1. No. 1. Edisi Online. https://core.ac.uk/download/pdf/294 882968.pdf. [23 Oktober 2020].

Misnawi, Ariza Budi Tunjung Sari,dan Hendi Firmanto. 2017. Flavor Kopi dan Pengukurannya. Makalah dalam Buku Kopi, Sejarah, Proses Produksi,Pengolahan, Produkai Hilir Dan Sistem Kemitraan.Yogjakarta. Gadjah Mada Univerity Press.

Soeparno, 1992. Diktat: Nutrisi dan Mikrobiologi. Yogyakarta: Universitas Gadjah Mada.

Sumartono, B , Sulistyowati dan Misnawi, 2005. Pengenalan Uji Organoleptik. Materi Pelatihan Uji Cita Rasa Kopi. Pusat Penelitian Kopi dan Kakao Indonesia.Jember

Solikatun, Kartono, D Tri, dan Demartoto, A. 2015. "Perilaku Konsumsi Kopi Sebagai Budaya Masyarakat Konsumsi: Studi Fenomenologi Pada Peminum Kopi di Kedai Kopi Kota Semarang”. J. Analisa Sosiologi. 4(1). Hal 60-74. https://jurnal.uns.ac.id/jas/article/vie w/17410/13908. [22 April 2020].

Sunarharum, W. B., Kiki F., Sudarminto S. Y., dan Mokhamad N. 2019. Sains Kopi Indonesia. Malang: UB Press.

Stokes CN, MG O'Sullivan and JP Kerry. 2017. Hedonic and descriptive sensory evaluation of instant and fresh coffee products. Eur Food Res Technol (2017) 243:331-340 DOI $10.1007 / \mathrm{s} 00217-016-2747-4$

Wardana, A.S. 2012. Teknologi Pengolahan Susu. Makalah Edisi Online.

https://www.kompasiana.com/leoric/5 c19ed3e43322f59a157c414/perbedaa n-susu-skim-dengan-susu-full-creammanakah-yang-cocok-untuk-diet\#. [19 September 2020]

Winarno. 2007. Kimia Pangan dan Gizi. Jakarta: Gramedia.. 
Widyotomo S. 2016. Penyangraian, Pembubukan dan Penyeduhan kopi.Makalah dalam Buku Kopi, Sejarah, Proses Produksi,Pengolahan, Produkai Hilir Dan Sistem Kemitraan.Yogjakarta. Gadjah Mada Univerity Press. 